Research Article

\title{
Incisional hernia: incidence, clinical profile, risk factors and prevention
}

\author{
Sharath Kumar $\mathbf{J G}^{1}$, Upendra Kumar $\mathbf{K}^{1}$, Mallikarjuna Manangi ${ }^{3}$, Madhu $\mathbf{K P}^{4}$, Arun $\mathbf{B J}^{\mathbf{2}}$, \\ Niranjan Nagaraj ${ }^{5} *$
}

\author{
${ }^{1}$ Department of Surgery, ${ }^{2}$ Department of respiratory Medicine, Kempegowda Institute of Medical Sciences, Bangalore, \\ India \\ ${ }^{3}$ Department of Surgery, Victoria Hospital, Bangalore Medical College and Research Institute, Bangalore, India \\ ${ }^{4}$ Department of Anaesthesia, Victoria Hospital, Bangalore Medical College and Research Institute, Bangalore, India \\ ${ }^{5}$ Department of Paediatrics, S P Medical College, Bikaner, Rajasthan, India
}

Received: 05 June 2016

Accepted: 09 June 2016

*Correspondence:

Dr. Niranjan Nagaraj,

E-mail: getniranjan806@yahoo.com

Copyright: (c) the author(s), publisher and licensee Medip Academy. This is an open-access article distributed under the terms of the Creative Commons Attribution Non-Commercial License, which permits unrestricted non-commercial use, distribution, and reproduction in any medium, provided the original work is properly cited.

\begin{abstract}
Background: Incisional hernias are very common. They are the second most common type of hernia after inguinal hernias. This study was undertaken to study the incidence and various risk factors leading to incisional hernia.

Methods: This prospective study was conducted in department of surgery, Sri Devaraj URS Medical College, Kolar, India from May 2010 to May 2012. All the cases were analyzed in various aspects like age, sex, parity, relative incidence, clinical presentation, nature of previous operation, site of previous scar, precipitating factors like obesity, wound infection, abdominal distension.

Results: The incidence is around 7.5\%. Patients in the age group of 30-60 years found to have highest incidence of incisional hernia. Females outnumbered the males with the ratio of $4: 1$. Incisional hernia was more common in patients with previous history of gynecological operation. Most of the patients presented with incisional hernia in the infra umbilical region.

Conclusions: Incisional hernias are iatrogenic and preventable by avoidance of midline incisions, especially in the infra umbilical region.
\end{abstract}

Keywords: Incisional hernia, Incidence, Risk factors, Prevention, Kolar

\section{INTRODUCTION}

Incisional hernias are very common. They are the second most common type of hernia after inguinal hernias. Approximately 4 million laparotomies are performed in the United States annually, 2-30\% of them resulting in incisional hernia. Between 100,000 and 150,000 ventral incisional hernia repairs are performed annually in the United States. ${ }^{1}$ Incisional hernias after laparotomy are mostly related to failure of the fascia to heal and involve technical and biological factors. Approximately 50\% of all incisional hernias develop or present within the first 2 years following surgery, and $74 \%$ occur within 3 years. ${ }^{1}$
Depending on size, the repair of an incisional hernia varies from simple suturing to major reconstruction of the abdominal wall with creation of muscle flaps and the use of large pieces of mesh. This can be done with an open approach or laparoscopy. Incisional hernia occurs in approximately 5-11\% of patient's subjects to abdominal operations. ${ }^{2}$ Many factors are associated with incisional herniation like age, sex, obesity, chest infection, type of suture material used and most important wound infection. All these present a challenging problem to the surgeon. Recent studies have shown that about 2/3'd appear within the first five years and that at least another third appears 5-10 year after operation. ${ }^{3}$ In 1993, Le Blanc reported the 
first case of laparoscopic incisional hernia repair with the use of synthetic mesh. The procedure involves the placement of a mesh inside the abdomen without abdominal wall reconstruction. The mesh is fixed with sutures, staples, or tacks. The recurrence rate of the laparoscopic repair is reported as equal as or less than that done with the open approach. Incisional hernia repair is considered a challenging procedure, especially in recurrent hernias, in which the chances of failure increase with each surgical attempt.

\section{Risk factors for hernia formation}

A $0.1 \%$ rate of acute laparotomy wound failure has been reported in the literature. ${ }^{1}$ The true rate of laparotomy failure is about $11 \%$, of these patients, $94 \%$ present with recurrence in the first 3 years after the operation. The real laparotomy wound failure rate is therefore 100 times greater than previously thought. The early mechanical failure, therefore, occurs early in the course of the disease, and the healing skin conceals a myofascial defect that enlarges or appears later. Perioperative shock is a recognized risk factor for incisional hernia formation. Upper midline incisions have a higher incidence of hernia formation than other types of incision do. ${ }^{1}$ Few studies was done on incisional hernia, hence this study was undertaken to study the incidence and various risk factors leading to incisional hernia.

\section{METHODS}

This prospective study was conducted in department of surgery, Sri Devaraj URS Medical College, Kolar, India from May 2010 to May 2012. Institutional ethical committee permitted for study. Informed consent was taken from patients and patient attenders. A prospective study of 30 cases of incisional hernias treated in R.L.Jalappa Hospital Kolar, India are collected consequently during the period of May 2010 to May 2012 with the help of available data. No particular criteria were adopted during selecting the patients for the study and cases were studied as per the proforma attached. Detailed history of the illness was taken as this is very important for the type and cause of hernia. A detailed general and local examination was made. All the cases were analysed in various aspects like age, sex, parity, relative incidence, clinical presentation, nature of previous operation, site of previous scar, precipitating factors like obesity, wound infection, abdominal distension. The contributory factors like chronic bronchitis, chronic constipation and enlarged prostate were particularly lock for. While presenting the cases, only relevant and positive findings were recorded in the proforma case sheet enclosed and a master chart dealing with all the aspects has been designed and presented. The diagnosis was made clinically in all the cases without difficulty. Routine investigations were done to obtain fitness for surgery. Collected data was tabulated and stastically analysed by using SPSS software.

\section{RESULTS}

The factors causing incisional hernia can be preventable; the incidence is around $7.5 \%$. Patients in the age group of 30-60 years found to have highest incidence of incisional hernia. Females outnumbered the males with the ratio of $4: 1$. Incisional hernia was more common in patients with previous history of gynecological operation. Most of the patients presented with incisional hernia in the infra umbilical region. More than half of the patients have presented with incisional hernia within 3 years of operation. Wound infection remains the most popular risk factor associated with wound failure.

Table 1: Incidence of inguinal hernia.

\begin{tabular}{|c|c|c|c|c|c|c|}
\hline \multirow[b]{2}{*}{$\begin{array}{l}\text { Types of } \\
\text { hernia }\end{array}$} & \multicolumn{2}{|c|}{$\begin{array}{l}\text { BL Coley } \\
\text { series }\end{array}$} & \multicolumn{2}{|c|}{$\begin{array}{l}\text { JB Shah } \\
\text { Bombay }\end{array}$} & \multicolumn{2}{|c|}{$\begin{array}{l}\text { RLJH } \\
\text { 2010-2012 }\end{array}$} \\
\hline & $\begin{array}{l}\text { No } \\
\text { of } \\
\text { cases }\end{array}$ & $\%$ & $\begin{array}{l}\text { No of } \\
\text { cases }\end{array}$ & $\%$ & $\begin{array}{l}\text { No } \\
\text { of } \\
\text { cases }\end{array}$ & $\%$ \\
\hline $\begin{array}{l}\text { Inguinal } \\
\text { hernia }\end{array}$ & 2793 & 93 & 880 & 88 & 650 & 81.25 \\
\hline $\begin{array}{l}\text { Incisional } \\
\text { hernia }\end{array}$ & 38 & 1.3 & 50 & 5 & 60 & 7.5 \\
\hline $\begin{array}{l}\text { Umbilical } \\
\text { and para } \\
\text { umbilical } \\
\text { hernia }\end{array}$ & 14 & 0.5 & 36 & 3.6 & 70 & 8.75 \\
\hline $\begin{array}{l}\text { Femoral } \\
\text { hernia }\end{array}$ & 54 & 1.5 & 22 & 22 & 5 & 0.62 \\
\hline $\begin{array}{l}\text { Epigastric } \\
\text { hernia }\end{array}$ & 101 & 3.3 & 12 & 1.2 & 15 & 1.87 \\
\hline
\end{tabular}

Table 2: Distribution of cases based on previous incision was made.

\begin{tabular}{|lll|l|}
\hline Name of operation & $\begin{array}{l}\text { Ponk } \\
\%\end{array}$ & $\begin{array}{l}\text { Goel and } \\
\text { Dubey \% }\end{array}$ & $\begin{array}{l}\text { Present } \\
\text { study }\end{array}$ \\
\hline Hysterectomy & 34 & - & 10 \\
\hline LSCS & 2 & 28.76 & 10 \\
\hline Tubectomy & - & - & 53.3 \\
\hline Appendisectomy & 16 & 3.42 & 10 \\
\hline $\begin{array}{l}\text { Gastrojejunostomy } \\
\text { + vagotomy }\end{array}$ & 11 & 12.32 & - \\
\hline Cholecystectomy & 21 & - & 3 \\
\hline $\begin{array}{l}\text { Closure of peptic } \\
\text { ulcer perforation }\end{array}$ & - & 15.06 & 13 \\
\hline $\begin{array}{l}\text { Colon and } \\
\text { colostomy } \\
\text { operations }\end{array}$ & 9 & - & - \\
\hline $\begin{array}{l}\text { Suprapubic } \\
\text { cystostomy }\end{array}$ & - & 15 & - \\
\hline Kidney operations & - & 9.58 & - \\
\hline Miscellaneous & 17 & 15.74 & - \\
\hline
\end{tabular}


Table 3: Various risk factors associated with incisional hernia.

\begin{tabular}{|lllll|}
\hline Risk factors & A.B. Thakore et al & \multicolumn{3}{l|}{ Present study } \\
\hline Nound infection & 35 & $\mathbf{\%}$ & Numbers & \% \\
\hline Wound gaping & 10 & 46.05 & 4 & 13.3 \\
\hline Late eventeration & 1 & 13.15 & 5 & 16.6 \\
\hline Chest complication & 10 & 1.3 & - & 0 \\
\hline Retention of urine & 2 & 13.15 & 5 & 0 \\
\hline Obesity & - & 2.63 & - & 20 \\
\hline Diabetes mellitus & - & - & 6 & 16.6 \\
\hline No complications & 24 & - & 5 & 16.0 \\
\hline Not mentioned & 14 & 31.5 & 5 & 0 \\
\hline
\end{tabular}

Table 4: Previous incision leading to incisional hernia.

\begin{tabular}{|lllllll|}
\hline \multirow{2}{*}{ Incision } & A.B. Thakore & & Goel - Dubey & \multicolumn{3}{l|}{ Present study } \\
& Number of cases & $\mathbf{\%}$ & Number of cases & $\mathbf{\%}$ & Number of cases & \% \\
\hline Lower midline & 51 & 67.10 & 65 & 44.6 & 16 & 53.3 \\
\hline Upper midline & 6 & 7.8 & 41 & 28.0 & 4 & 13.3 \\
\hline Para median & 75 & 19.65 & 21 & 14.2 & 1 & 3.3 \\
\hline Mc burney & 4 & 5.2 & 5 & 3.6 & 3 & 10 \\
\hline Transverse (pfann enstial) & - & - & - & - & 6 & 20 \\
\hline Oblique lumbar & - & - & 14 & 9.6 & - & - \\
\hline Total & 76 & 100 & 146 & 100 & 30 & 100 \\
\hline
\end{tabular}

\section{DISCUSSION}

A study of 30 cases of incisional hernia admitted to RE Jalappa Hospital during the year of May 2010 to May 2012 was made. The following is the analytical results of all the cases and conclusion drawn from it. In this study out of 800 cases of hernias operated in our hospital, incisional hernia constitutes $7.5 \%$. In Devlin HB studies, De Bord JR studies, Gibson CL studies series the incidence is $1.7 \%, 11.5 \%, 5 \%$, respectively. ${ }^{4-6}$

Female predominated the picture in my study with 4:1 ratio $(80 \%)$ with that of males. Though Thomas A Santora stated the male gender has propensity to develop incisional hernia. ${ }^{7}$ Ellis have obtained a $64.6 \%$ of female population in their study of 342 patients. ${ }^{8}$ Incidence of incisional hernia is more common in females in our country may be because of multiple child births which leave the abdominal wall weak. The incidence of incisional hernia is higher in 30-60 years age group with mean age of 45 years in my study. Ellis in their study noticed a >mean age of 49.4 years. ${ }^{8}$ The youngest patient in my study was 23 years old and oldest was 70 years old.

Majority of patients were house wives and agricultural workers were the next common occupants. In nearly $83 \%$ of patients the site of hernia was infraumbilical, of which only three patients had incisional hernia following appendisectomy, the rest of patients underwent gynecological operations, most commonly tubectomy, hysterectomy and caesarian section. This may be due to the frequency of female pelvic surgery through infraumbilical midline approach, where the linea Alba is thinner and less well protected compounded by multiparty. Jack Abrahamson stated that lower abdominal incision apart from other causes is one of the factors with a higher rate of incisional hernia and recurrence after repair. In my study also, incisional hernia is more common after lower midline incisions. ${ }^{3}$

In considering risk factors promoting incisional hernia, wound infection and dehiscence is the commonest. It occurred in $30 \%$ of patients in my study. This is comparable with that of JN Parekh studies. ${ }^{9}$ There were six obese patients with incisional hernia out of 30 cases $(20 \%)$ in my study. Ellis noted 30 obese patients who developed incisional hernia out of 200 cases i.e. $15 \%$, though other factors also play a role in causation of incisional hernia. ${ }^{8}$ Ellis group found that obesity was associated with a threefold increase in herniation and recurrence, but it is difficult to pin point the actual cause for this or technical factors involved.

All studies showed that most of the incisional hernia appears within the first year or second year after surgery. In this study, the history reveals $54 \%$ of them developed 
hernia within 3 years of operation. Jack Abrahamson noticed $80 \%$ of hernia appearing within first 2 years Kings north AN and studies $77 \%$ developed within 3 years after operation. ${ }^{3,10}$ Late hernias were not common up to 5 years after operation. Mudge and Hughes noticed $35 \%$ manifesting after 5years and in my study they accounted for $46 \% .^{11}$ The probable cause may be because of aging and weakening of tissues and raised intraabdominal pressure associated with chronic cough, constipation. Wound infection and wound gaping constituted $30 \%$. Obesity constitutes $20 \%$, diabetes mellitus constitute $16.6 \%$ and postoperative respiratory complication accounted for $16.6 \%$. In $16.6 \%$ of patients no complications were found.

\section{CONCLUSION}

Incisional hernias are iatrogenic and preventable by avoidance of midline incisions, especially in the infra umbilical region. Incisional hernia was more common in patients with previous history of gynecological operation. Proper preoperative preparation of the patients with high risk is as important in preventing recurrence.

Funding: No funding sources

Conflict of interest: None declared

Ethical approval: The study was approved by the institutional ethics committee

\section{REFERENCES}

1. Laparoscopic repair of incisional hernia. Available at http://emedicine.medscape.com/article/1892407overview. Accessed on 10 May 2016.

2. Casser K, Munro A. Surgical treatment of incisional hernia. Br J Surg. 2002;89:534-45.

3. Abrahamson J. Hernias. In Maingot's abdominal operations, $1^{\text {st }}$ edition. New York, McGrawHill;1997:479-573.

4. Devlin HB, Dudley H, Pories W, Carter D. Incisional hernia. In Rob and Smith operative surgery. $4^{\text {th }}$ edition. USA, CRC Press; $1983: 428-440$.

5. Bord JR, Bendavid R, Abrahamson J, Phillip EH. Prosthesis in hernia surgery. In abdominal wall hernias. Principles and management. $1^{\text {st }}$ edition. New York, Springer-Verlag; 2001:16-30.

6. Gibson CL. Operation for cure of large ventral hernia. Am Surg. 1920;14:214-7.

7. Santora TA, Roslyn JJ. Incisional hernia. Surg Clin N Am. 1993;73(3):557-70.

8. Ellis H, George CD, Gajaraj H. Incisional hernias; when do they occur. Br J Surg. 1983;70(5):290-1.

9. Parekh JN, Shah DB, Thakore AB. Incisional hernia; a study of 76 cases. Ind J Surg. 1988:49-53.

10. Kingsnorth AN, Shivarajasingham N, Warg S, Buttler M. Open mesh repair of incisional hernia with significant loss of domain. Ann R Coll Surg Eng. 2004;86(5):363-6.

11. Marjorie M, Hughes LE. Incisional hernia: a 10 year prospective study of incidence and attitudes. $\mathrm{Br} \mathrm{J}$ Surg. 1985;72(1):70-1.

Cite this article as: Kumar SJG, Kumar UK, Manangi M, Madhu KP, Arun BJ, Nagaraj N. Incisional hernia: incidence, clinical profile, risk factors and prevention. Int Surg J 2016;3:1292-5. 